\title{
Emilia Zimnica-Kuzioła*
}

\section{EMIGRACJA DO ŚWIATA KLAUZUROWEGO - NA PODSTAWIE RELACJI SIÓSTR ZAKONNYCH}

\begin{abstract}
Abstrakt. Celem artykułu jest analiza relacji sióstr zakonnych na temat ich emigracji do świata klauzurowego. Spośród kilkudziesięciu wypowiedzi sióstr (reprezentujących różne polskie zgromadzenia zakonne) na temat ich wyboru drogi życiowej wybrałam najciekawsze i najobszerniejsze. Teksty (łącznie 20) zamieszczone na stronach internetowych zakonów poddałam analizie treści, nakierowanej na wyodrębnienie dominujących wątków tematycznych. Mają one ważny walor kognitywny, pokazują dynamikę powołania do życia konsekrowanego, które jest nie tylko aktem osobowym, ale i fenomenem społecznym; pozwalają też na wyodrębnienie czynników decydujących o zakonnej emigracji. Oprócz segmentacji wypowiedzi według klucza semantycznego, w podstawowym zakresie uwzględniłam też ich cechy językowe.
\end{abstract}

Słowa kluczowe: zakony w Polsce, analiza świadectw sióstr zakonnych, dynamika powołania.

Trudno zrozumieć motywy emigracji ze świata młodej dziewczyny, która zostawia za murami klasztoru swoją przeszłość, najbliższych, znajomych. Dla wielu ludzi jest to niemal równoznaczne $\mathrm{z}$ dobrowolnym skazaniem się na więzienie. Asceza, wierność, uległość, zamknięta przestrzeń, wyrzeczenie się kontaktów (lub maksymalne ich ograniczenie) z otoczeniem zewnętrznym, by ukierunkować się na modlitwę, kontemplację, adorację, rezygnacja ze wszystkich przedmiotów potencjalnie dystrakcyjnych (telefonów komórkowych, komputerów osobistych) wydają się niekompatybilne z etosem współczesności.

Na wstępie warto przytoczyć dane statystyczne dotyczące polskich zakonów klauzurowych:

W Polsce w zakonach klauzurowych jest 1349 zakonnic. 1220 sióstr z klasztorów kontemplacyjnych jest po profesji wieczystej (czyli złożyły już śluby wieczyste w zakonie), pozostałych 129 to profeski czasowe (juniorystki), nowicjuszki i postulantki. Średni wiek polskiej

* Dr, Katedra Socjologii Sztuki, Instytut Socjologii, Wydział Ekonomiczno-Socjologiczny, Uniwersytet Łódzki, ul. Rewolucji 1905 r. 41/43, 90-214 Łódź; e-mail: emilia.zimnica@onet.eu. 
zakonnicy żyjącej w klauzurze wynosi nieco ponad 52 lata. Życie zakonnicy klauzurowej koncentruje się na modlitwie, ale mniszki zajmują się też pracami ręcznymi, m.in. haftowaniem i szyciem szat liturgicznych, wypiekiem opłatków i komunikantów (KAI 2014)․․․

Badacze społeczni rzadko podejmują problem wspólnot życia konsekrowanego, niewiele jest prac na temat wspólnot zakonnych męskich i żeńskich w Polsce w XXI w. ${ }^{2}$ Tym bardziej cenna jest książka Józefa Baniaka, studium socjologiczne z 2012 r., w której autor omówił problem powołań kapłańskich i zakonnych na przestrzeni 110 lat historii Polski w ramach teorii potrzeb oraz teorii wartości. Autorzy prac akademickich (licencjackich i magisterskich) najczęściej ukazują zgromadzenia zakonne w świetle Goffmanowskiej charakterystyki instytucji totalnej (zob. m.in. Marczak 2008; Lis zkowska 2010).

W potocznej świadomości funkcjonuje wiele wyobrażeń i stereotypów dotyczących życia za klauzurą. Można je skonfrontować z wypowiedziami zakonnic, które zamieszczają swoje „świadectwa” na internetowych stronach własnych zgromadzeń. Świadectwo jest jednak szczególną formą dyskursu, jego głównym celem jest zachęta i dodanie odwagi niezdecydowanym co do wyboru drogi życiowej. Ów prozelityczny charakter przesądza w zasadzie wymowę zwierzeń sióstr zakonnych. Nie znajdziemy tu narzekania na izolację, monotonię, rutynę codzienności, ograniczenia, ciężką pracę w kuchni czy w ogrodzie, na konieczność bezwzględnego posłuszeństwa, eliminowania pragnień bliskości drugiego człowieka, kanalizowania naturalnych potrzeb, na konieczność budowania wspólnoty z oso-

${ }^{1}$ Jak pisze K. Dębowska, proces formacji zakonnej trwa całe życie: zaczyna się od postulatu, nowicjatu i junioratu, a potem następuje stała inkorporacja zakonnych reguł w codziennym życiu mniszki: „Okres przed nowicjatem, trwający sześć miesięcy lub dłużej, nazywa się postulatem. Ma on na celu zbadanie powołania kandydatów lub kandydatek, stopnia dojrzałości, która czyni ich zdolnymi do podjęcia obowiązków właściwych drodze życia zakonnego, a także sprawdzenie poziomu ich wiedzy religijnej. Postulat ułatwia kandydatom przejście z życia świeckiego do życia prowadzonego w nowicjacie. Okres nowicjatu nie jest równomierny - trwa od roku do dwóch lat, a ze względu na swój szczególny charakter i cel jest czasem swoistego odosobnienia i skupienia. Rolę podstawową odgrywają w nim mistrzowie i mistrzynie, którzy zapoznają nowicjuszy z regułą, konstytucjami, zwyczajami i zasadami życia zakonnego. Nowicjusze są wprowadzani w ducha modlitwy, w pracę nad sobą i w praktykę rad ewangelicznych, do których później zobowiążą się mocą ślubów zakonnych. Nowicjat służy dokładnemu rozpoznaniu powołania do danego zakonu, zapoznania nowicjuszy ze sposobem życia w nim, potwierdzeniu ich zdolności do życia wspólnotowego, ocenie zdrowia i uzdolnień do wykonywania prac związanych z celem specjalnym wspólnoty zakonnej. Po ukończeniu tego okresu formacji zakonnej nowicjuszki i nowicjusze składają pierwsze śluby zakonne, czyli profesję czasową. Następnie formacja zakonna jest kontynuowana w junioracie, kiedy młodzi zakonnicy pogłębiają swoje umiejętności życia według rad ewangelicznych. Okres ten trwa zwykle pięć lat, a wówczas zakonnice i zakonnicy zgłębiają swoją wiedzę religijną i wdrażają się w specyficzne prace swojego zakonu i zgromadzenia. Formacja osób zakonnych nie kończy się ślubami wieczystymi. Przepisy konstytucji i programy formacyjne w każdym instytucie określają ramy formacji stałej, zwanej formacją permanentną, która ma na celu dalsze pogłębianie rozwoju duchowego osób konsekrowanych" (D ę b o w s k a 1998: 14).

${ }^{2}$ Kompendium wiedzy o zakonach stanowi książka Bogumiła Ł o z i ń s k i e g o (2009). 
bami o różnych temperamentach, charakterach itd. Zamiast tego czytamy zapewnienia o bezgranicznym szczęściu i radości osób konsekrowanych, emigrantów do świata klauzurowego. Siostry mówią językiem religijnym, że wybór stanu zakonnego, czyli „powołanie”, ma wymiar tajemnicy, ale ma też wymiar socjologiczny, jest faktem społecznym, bowiem decyzja o wstąpieniu do zakonu rozgrywa się w indywidualnej historii życia dziewczyny. Socjologa interesują nade wszystko uwarunkowania społeczno-kulturowe powołan, oddziaływanie środowiska zewnętrznego, osłabiającego bądź wzmacniającego powołanie zakonne. Niemniej jednak ma on też świadomość znaczenia indywidualnych predylekcji i aktywności jednostki dokonującej tak poważnego życiowego wyboru.

Podczas lektury wypowiedzi sióstr na pierwszy plan wysuwa się głębokie przekonanie ich autorek o pewnym determinizmie, jakby to nie one same zdecydowały o emigracji ze świata. Są przeświadczone, że inicjatywa była zewnętrzna - to Bóg je wybrał, miał wobec nich ,plan” i tak je prowadził przez życie, by ostatecznie doprowadzić za mury klasztoru: „Zrozumiałam, że tak naprawdę to reżyserem całego mojego życia nie jestem ja, ale Pan Bóg”, „Czułam w sobie wezwanie Boga" - mówią mniszki. Ich zadaniem - jak same stwierdzają - było odczytanie tego wezwania i przyjęcie „daru”, „łaski”. Inne określenia, jakie pojawiają się w ich świadectwach, to: „zaszczyt”, „szczególne wyróżnienie” i chyba najczęściej „powołanie”. W mowie potocznej to ostatnie pojęcie oznacza określone uzdolnienia, predyspozycje do wykonywania zawodu, z którym wiąże się gotowość do poświęcenia, nastawienie autoteliczne i altruistyczne (nauczyciel, lekarz). W słowniku religijnym termin ,powołanie” to inaczej misja, zadanie, jakie wypełnia człowiek w swoim życiu w odpowiedzi na wezwanie Boga. Szczególnym rodzajem powołania jest powołanie do życia kapłańskiego i zakonnego, których istotą jest poświęcenie życia Bogu. Zdaniem Józefa Baniaka

powołanie kapłańskie i zakonne można interpretować z dwóch perspektyw:

a) nadnaturalnej - wtedy oznacza ono odpowiedź lub reakcję człowieka wybranego na ,zawołanie" płynące doń od Boga,

b) naturalnej - wtedy powołanie traktujemy jako fakt lub zjawisko społeczne, w którym można widzieć określoną wartość egzystencjalną lub specyficzną potrzebę człowieka - kobiety i mężczyzny.

U podstaw tak pojmowanego powołania znajduje się swobodna decyzja wybranego człowieka, która wpływa na decyzję i wybór powołania jako znaczącej egzystencjalnie potrzeby i wartości (B a niak 2012: 33).

Dla terminologicznej jasności należy jeszcze wyjaśnić słowo „świadectwo” jako „potwierdzenie czegoś przez świadka” - w kontekście religijnym termin ten odnosi się do formy wypowiedzi ustnej bądź pisemnej, która ma za zadanie przekonać innych o działaniu czynnika nadprzyrodzonego w życiu człowieka. Ponieważ celem świadectwa jest zachęta dla implikowanego odbiorcy, danie przykła$\mathrm{du}$, przekonanie niezdecydowanych, zawiera ono pewne elementy perswazyjne, 
nakłaniające. Autorzy tego typu narracji stosują określone środki językowe podkreślające emocjonalność przekazu i intencjonalnie mobilizujące do podjęcia określonego działania.

Warto spytać, czy uzasadnione jest w przypadku podjęcia decyzji o wyborze drogi zakonnej użycie sformułowania „emigracja”? Zasadność paraleli wynika stąd, iż jest to przemieszczenie się do innego świata, wymagające zbudowania nowej tożsamości, przyjęcia nowej roli. Zakon to nowy etap życia, wiążący się nie tylko z egzystencjalną transformacją, ze zmianą miejsca zamieszkania, lecz także z koniecznością automodelowania i interioryzowania zasad obowiązujących w nowej rzeczywistości. Emigracja do wspólnoty zakonnej ma charakter dobrowolny, jest aktem wolnej woli. Co prawda, w praktyce życia społecznego istnieją mniej bądź bardziej subtelne formy nakłaniania, zachęty, ale nie presji. Emigracja tego typu nie powinna być ,ucieczką przed” (problemami osobistymi, zawodowymi), ale wynikać z poszukiwania „czegoś więcej” (głębi życia duchowego, możliwości realizacji ewangelicznych wartości, itp.). Intencje emigrantki powinny być czyste, czyli stricte religijne.

Siostry zakonne spotykają się nieraz z zarzutem, że na klauzurowej emigracji prowadzą życie próżniacze - nie tylko nie robią nic pożytecznego, ale marnują swoje talenty (niektóre wykształcone, po studiach farmaceutycznych, administracyjnych, wykorzystują swoje umiejętności, służąc zakonowi). One - zgodnie ze zinternalizowanym skryptem religijnym - wyrażają pewność, że emigracja tego typu ma głęboki sens, że wpływają na losy świata (modlą się o pokój), a ich ofiara ma znaczenie dla innych, dla ich zbawienia. To świadczy o ich silnej wierze w moc modlitwy i o poczuciu misyjności:

Życie mniszek zostaje przemienione w skarb dla Kościoła - cóż może być cenniejszego nad to? Przecież nikt z nas nie potrafi swoim staraniem przedłużyć swych dni na tej ziemi, ale za to Bóg daje o wiele więcej - pozwala te dni przemienić tak, by żadna minuta nie była zmarnowana i przyniosła pożytek całemu światu (siostra Maria, kapucynka z Przasnysza).

Emigrantka ze świata zmienia się fizycznie: ścina włosy, zakłada welon, strój - uniform: „Kiedy zacznę nosić habit? To najlepszy ubiór dla mnie ze wszystkich możliwych. Lekki, bo bez balastu ziemskich trosk i z dystansem do tego, za czym ugania się świat!" - deklaruje jedna z zakonnic (s. M. Klara), a jednak zaraz dodaje: „rozstanie ze świeckimi ciuchami nie było łatwe”. Przemiana zewnętrzna jest jednak tylko znakiem wewnętrznej metanoi, która w języku socjologicznym nazywana jest alternacją (B e r g e r, L u c k m a n n 2010). Kobieta, która przechodzi formację zakonną, dostaje się pod opiekę „mistrzyni życia duchowego”, przewodniczki i pośredniczki w dostępie do nowej rzeczywistości, w interioryzacji zasad nowego świata jest też wspierana przez wspólnotę. P. L. Berger i Th. Luckmann zaznaczają, że dla skuteczności alternacji ważne jest - szczególnie we wczesnych stadiach (tutaj w fazie nowicjatu) - fizyczne oddzielenie od świata dotychczas 
zamieszkiwanego (t a m że: 231). Izolacja sprzyja asymilacji w nowym środowisku i redefinicji doświadczeń przeszłych w świetle nowej rzeczywistości. W wyniku silnej identyfikacji z nowymi „znaczącymi innymi” ugruntowaniu ulega nowa hierarchia wartości i trwale mienia się katalog potrzeb. Symbolicznym aktem alternacji jest zmiana imienia mniszki. Siostry krytycznie wypowiadają się o życiu w świecie; one wybrały życie ukryte, w dobrowolnej izolacji, za kratą klauzury (deprecjonowanie świata poza klauzurą i waloryzowanie zamknięcia jest psychologicznie zrozumiałe w świetle teorii podecyzyjnego dysonansu poznawczego; post factum wzrasta atrakcyjność opcji wybranej i spada subiektywny walor opcji odrzuconej). Emigracja do życia klauzurowego wiąże się z intensywną koncentracją na sferze sacrum (modlitwą, lekturą książek na temat życia wewnętrznego, skupieniem i milczeniem podczas posiłków) ${ }^{3}$.

Każda wspólnota religijna oferuje jednostce pewne sposoby opowiadania o osobistych doświadczeniach [...]. Wszelkie doświadczenia wymagają zatem istnienia jakiegoś słownika, za pomocą którego się je prezentuje, i pewnych ram narracyjnych, w jakich się je umieszcza. Pojawia się zatem przekonanie, że jednostka nie tylko ma pewne doświadczenia religijne, ale także - a może przede wszystkim - opowiada o nich według pewnych wspólnotowych, a zarazem kulturowych wzorów" - pisze N. M o d n i ck a (2007: 178).

Relacje sióstr pokazują uniwersalne mechanizmy prowadzące do życia zakonnego, można odkryć w nich homologię doświadczeń i wyeksponować wspólne motywy biograficzne. W dyskursach sióstr zakonnych wyodrębniłam stałe elementy strukturalne, ponieważ większość wypowiedzi zawiera te same wątki tematyczne: wpływ grup odniesienia, szczególnie rodziny, znaczących innych; doświadczenie religijne; świadomość „inności”, proces dojrzewania decyzji o wstąpieniu do zakonu; rozterki; wybór konkretnego zgromadzenia; reakcja

${ }^{3}$ Przykładowo, modlitwa wspólnotowa w klasztorze norbertanek w Imbramowicach trwa ok. 6 godzin dziennie. Codzienność sióstr wypełniona jest też pracą w kościele, klasztorze, ogrodzie. Norbertanki wykonują prace krawieckie, hafciarskie, podczas których powinny zachowywać milczenie. W planie dnia przewidziany jest czas na odpoczynek (tzw. rekreacja odbywa się we wspólnocie). Chociaż posiadają telewizor, radio i Internet, korzystają z nich incydentalnie. „Nie interesują się szczegółowo polityką i tym, co się dzieje na świecie, gdyż jako siostry klauzurowe powołane są przede wszystkim do modlitwy" - czytamy na stronie internetowej zgromadzenia. Jest to zatem szczególna forma życia zbiorowego, emigracja, z którą nie powinna się wiązać nostalgia za tym, co utracone. Siostry nie śledzą tego, co dzieje się poza murami klasztoru, lecz „wszystkie sprawy świata powierzają Bogu". Plan dnia w klasztorze w Imbramowicach ukazuje pracowite życie sióstr - ich dzień rozpoczyna się o 5.00 rano (wyjątkowo w niedzielę o 5.30), kończy „milczeniem kanonicznym” o 20.30. Na stronie internetowej zgromadzenia czytamy: „Poza śpiewaną modlitwą liturgiczną [Liturgia Godzin] we wspólnotowym planie dnia przewidziane są także: studium Pisma Świętego, medytacja, modlitwa różańcowa, adoracja Najświętszego Sakramentu, nieustanna Nowenna do Pana Jezusa Cierpiącego - zwłaszcza w intencjach tych, którzy listowo i telefonicznie proszą nas o modlitwę - a także Koronka do Miłosierdzia Bożego, litanie i inne nabożeństwa" (Klasztor $i$ wspólnota $d z i s$, , http://www.imbramowice.norbertanki.org/p1/klasztor-i-wspolnota-dzis, 20.02.2015). 
najbliższych; świadomość tego, co się zyskuje i traci; pierwsze wrażenia w nowym świecie; zapewnienie o szczęściu i zachęta dla osób myślących o zakonie, ale jeszcze niezdecydowanych. Krótko omówię każdy z wyodrębnionych tematów, ilustrując go wybranymi (w każdym przypadku kilkoma) cytatami z zebranego materiału empirycznego.

W religijności jednostki ważnym, rudymentarnym parametrem jest doświadczenie religijne, definiowane jako subiektywne odczucie kontaktu z numinosum, istotą boską, ostateczną rzeczywistością, z czynnikiem nadprzyrodzonym (Glo c k, S tark 1965: 41-43). W chrześcijaństwie przedmiotem wiary jest osobowy Absolut, w wyznaniu katolickim cześć oddawana jest trzem osobom boskim (Ojciec, Syn i Duch Święty), Maryi i licznym świętym. Lee A. Kirkpatrick nazywa ich Doskonałymi Obiektami Przywiązania (J e liń s k a 2009: 157-173). W świadectwach sióstr zakonnych relacja na temat odczucia bliskości Boga (Chrystusa) stanowi dominantę. Niewidzialny, niematerialny Bóg jest bytem, z którym one prowadzą dialog; bytem, który budzi emocje, miłość, fascynację, zachwyt, euforię, entuzjazm, tęsknotę (określenia uczuć pochodzą ze świadectw sióstr zakonnych) ${ }^{4}$. Mniszki zdradzają bezpieczny styl przywiązania, piszą o zaufaniu, zakochaniu, „emocjonalnym porwaniu”. Jezus staje się ich Oblubieńcem, Najdroższym, Umiłowanym (analogia do Pieśni nad Pieśniami), z którym nawiązują bezpośrednią duchową (by nie powiedzieć romantyczną) więź. Dlatego tak chętnie emigrują w ciszę, kontemplację, niewerbalną medytację. Uciekają od wyuczonych formuł, na modlitwie nie tylko proszą, ale wielbią Boga i dziękują mu za wszystko, co je spotyka. Przyznają, że osobowa relacja z Jezusem i innymi Doskonałymi Obiektami Przywiązania jest fundamentem ich trwania na emigracji w świecie za klauzurą:

On był (i jest) ze mną każdego dnia, przez co życie nabiera radości, sensu, kolorów [...]. Zaczęłam wchodzić we własny, niedostępny dla nikogo innego świat, poczułam Jego bliskość: były to chwile modlitwy, bycia sam na sam z Bogiem moim. Tak więc już w młodym wieku miałam swoje Boże „tajemnice” (siostra Zofia).

Potrafiłam przez dłuższy czas wpatrywać się w Ukrzyżowanego, dziękować Mu za Jego miłość, mówić Mu o mojej miłości ku Niemu, po prostu trwać przy Nim. Z każdym dniem Jezus stawał mi się coraz bliższy, kochałam Go coraz bardziej (siostra zakonna, 30 lat).

${ }^{4}$ R. Otto, przedstawiciel fenomenologii, charakteryzował uczucia religijne poprzez kategorie tremendum et fascinosum. Przedmiot religijnego doświadczenia (numinosum) jest odczuwalny dzięki sensus numinis (apriorycznej podmiotowej zdolności) (O t t o 1993). O emocjach w religijności pisze m.in. Michael Hammond, autor teorii maksymalizacji afektu. Zgodnie z jego ujęciem jednostka poszukuje pozytywnych emocji i dąży do utrzymania ich wysokiego poziomu. Religia pozwala przezwyciężyć efekt habituacji, ,ponieważ święte przedmioty i byty ze świata ponadzmysłowego stanowią źródło pobudzenia emocjonalnego". Ponadto, zdaniem Hammonda, uczestnictwo w kulcie religijnym skutecznie obniża poziom emocji negatywnych (T u rn e r, S te t s 2009: 303). Jeszcze inną koncepcję związaną z problematyką emocji w religijności jednostki i zbiorowości znajdujemy u Randalla Collinsa (teoria rytuału interakcyjnego) (C o 11 in s 2011). 
Pokazuje mi swoją ogromną miłość i pozwala doświadczać swojej żywej obecności na modlitwie i w codziennej szarości dnia. Wiem, Komu zawierzyłam swoje życie. Wierzę, że na Jezusa mogę zawsze liczyć (siostra juniorystka).

Nie sposób nie zauważyć w tych relacjach analogii do związku między dwojgiem ludzi - siostry mają poczucie, że Jezus nawiązuje z nimi osobową więź, a ponieważ jest Doskonałym Obiektem Przywiązania, daje więcej miłości niż człowiek. I choć ten wymiar nazywany bywa ,wyobrażoną interakcją”, dla sióstr zakonnych interakcja ta jest źródłem szczęścia. Istnienie tej paraleli potwierdza Z. J. Zdybicka, która pisze:

Człowiek nie jest w stanie urzeczywistnić doskonałej więzi osobowej z „ty” ludzkim. Każdy związek międzyludzki zawiera w sobie jakiś brak; zdarzają się nieporozumienia, zdrady. Człowiek jednakże, pomimo wszystko, pragnie „komunii doskonałej”. Z głębi ludzkiego ,ja” wypływa bowiem apel domagający się zupełnego, nie narażonego na zdradę darowania się (oddania) drugiemu. Zdaniem Marcela, taką intersubiektywną komunię może człowiek urzeczywistnić tylko z „TY” absolutnym, z Bogiem. Tylko w tej komunii nie jest możliwy ani zawód, ani zdrada (Z d y b i ck a 1984: 106).

\section{Oto charakterystyczna wypowiedź mniszki:}

Czas ogólniaka, a jeszcze bardziej czas studiów, traktowałam, przeżywałam jako okres mego narzeczeństwa, co nadawało romantyczny charakter mojemu powołaniu - wybraniu do wyłącznej więzi z Jezusem. Znamienne jest, że to odczucie potęgowało się, gdy widziałam zakochane pary (a jest ich „cała masa” w dużym mieście i poza nim) mijane, spotykane często w różnych miejscach. Miałam zawsze przeświadczenie: nie idę bynajmniej sama - ale zawsze z moim niewidzialnym Narzeczonym, który wciąż jest ze mną i nie muszę się z Nim z żalem rozstawać po randce - jaki On wielki, wspaniały, niezawodny! Nie można było wybrać lepiej - przecież On jest sprawcą wszelkiej miłości, również międzyludzkiej. Czyli potrafi kochać bardziej od człowieka. Te doświadczenia były świetnym zabezpieczeniem przed możliwym kompleksem braku czegoś, a raczej kogoś - szczególnie w tym właśnie okresie młodości, gdy wiele rówieśnic miało już swoich chłopaków, a rodzina i znajomi wykazywali zainteresowanie, czy ja też już kogoś poznałam [...]. Obłóczyny, śluby pierwsze, czasowe, wieczyste - z pewnością wielkie przeżycie, tym bardziej, że w dość szerokim gronie sióstr i rodziny, ale to były tylko formalności „legalizacji” mojego związku z Jezusem, zawartego, gdy spojrzał z miłością na młodą, ufającą Mu dziewczynę i powiedział: „Pójdź za Mną (siostra M. Klara).

Siostry retrospektywnie zwracają uwagę na własne predyspozycje, inklinacje do przeżywania życia głębiej niż ich rówieśnicy. Mają świadomość ,inności” i „obcości”. Wspominając szkolne czasy, stwierdzają brak pełnej satysfakcji z kontaktów z rówieśnikami, sugerują, że miały inne potrzeby, inny horyzont aksjologiczny. Sfera religijna była dla nich bardzo ważna, uczestnictwo w rytuałach religijnych stanowiło autentyczną potrzebę. Nieraz - w obawie przed złośliwymi komentarzami i niezrozumieniem - ukrywały przed otoczeniem swoje zainteresowanie sferą sacrum: 
Z natury byłam żywa, wesoła, lubiłam się ładnie ubierać, miałam dużo koleżanek i kolegów. Pomimo to czułam zawsze pewien psychiczny dyskomfort, pewien niedosyt. Pociągała mnie cisza, samotność, w której pragnęłam znaleźć Boga. Zaczęłam się zastanawiać nad sobą, nad celem swojego życia i pytałam sama siebie, do czego pragnę dążyć. Wtedy uświadomiłam sobie, że to wszystko, co mnie otacza, nie zaspokoi mojego serca, że te wszystkie rzeczy zewnętrzne tylko odciągają mnie od Boga i nie są w stanie nasycić moich tęsknot i duchowych pragnień (siostra Zofia).

Regularnie brałam udział w spotkaniach klasowych, które nie miały w sobie wielkich wartości. Jak to młodzież, która bez obecności dorosłych robi, co chce. Uczęszczałam, bo nie chciałam się wyłamać. Kiedy zaczęły się pojawiać różnego rodzaju używki, moje odmowy były przedmiotem wyśmiewania i poniżenia (siostra Ewa).

We wszystkich relacjach zakonnic ważnym wątkiem jest religijna socjalizacja w domu rodzinnym, w szkole, w otoczeniu społecznym. Siostry wywodzą się ze środowisk konfesyjnych, ,znaczącymi innymi” w ich dotychczasowej biografii były osoby wierzące (rodzice, kapłani, siostry zakonne). Religijność przejętą od innych rozwijały, uczestnicząc w ruchach katolickich - Odnowie w Duchu Świętym, ruchu Światło-Życie („,oazie”), w pielgrzymkach, rekolekcjach organizowanych w parafiach i poza parafią, najczęściej podczas wakacji.

Rodzice moi byli religijni i często w domu słyszałam o Bogu. Czytane było Pismo Święte [...] (siostra Zofia).

Największym autorytetem w moim życiu był i nadal jest mój już dziś nieżyjący Ojciec. To On położył pod moje życie fundament, na którym wzrastało wszystko inne, między innymi i moje powołanie. Patrzyłam na Jego życie, słuchałam Jego słów i wszystko chowałam głęboko w sercu. W Jego życiu zawsze Bóg był na pierwszym miejscu. Codzienna Msza św., nabożeństwa majowe, czerwcowe, październikowe itd. Często powtarzał: „Dziecko, nie ma dla mnie większej radości, jak widzę, gdy przystępujesz do Komunii św.”. Nie zabiegał o to, co ziemskie, bo, jak mówił, zabierzemy ze sobą tylko to, co ma wartość wieczną. Ponieważ Ojca kochałam bardzo, dlatego nie chciałam Go w niczym zasmucić. Starałam się wprowadzać w życie to wszystko, czego mnie uczył słowami, a szczególnie swoim życiem (siostra zakonna, lat 56).

Kościół, parafia, wspólnota, schola - to miejsca, które od dzieciństwa były mi bliskie. Po wypełnieniu obowiązków szkolnych i domowych z wielką radością biegłam tam, gdzie było inaczej niż wszędzie. Bardzo ważną osobą był dla mnie kapłan. On w moich oczach był inny niż wszyscy ludzie. Myślę, że to, jak się mówiło o kapłanie w domu rodzinnym, sprawiło, że moje spojrzenie było właśnie takie (siostra Ewa).

Decyzja o wstąpieniu do zakonu poprzedzona była szeregiem antecedensów. Różni ludzie, sytuacje i życiowe wydarzenia doprowadziły każdą z sióstr do furty klasztornej. Nie mówią o nagłej iluminacji, ale o subiektywnym odczuciu atrakcyjności religijnego modelu życia. Uczestnicząc w rytuałach religijnych, odczuwały pozytywne emocje, spokój i radość, ale według zasad psychologii 
powołania, „fundament musi być silniejszy niż emocjonalny” (To rel1ó 2014), warunkiem sine qua non jest też wspomniana już „czystość intencji”, a zatem nieinstrumentalne traktowanie sacrum i ugruntowana decyzja emigracji ze świata. Jak wynika $\mathrm{z}$ wypowiedzi sióstr, $\mathrm{w}$ tym procesie dojrzewania decyzji o emigracji klauzurowej ważne były momenty emigracji wewnętrznej (stany wyciszenia, skupienia, modlitwy), które generowały pragnienie odkrycia terra incognita, wkroczenia w nową rzeczywistość i implikowały określony sposób funkcjonowania w świecie zewnętrznym.

W wypowiedziach sióstr widoczne są religijne schematy poznawcze, religijne atrybucje - fakty ze swojego życia interpretują one przez pryzmat powołania:

Przychodzi w życiu człowieka taka chwila, kiedy Bóg się objawia, a my nie zawsze potrafimy odczytać Jego znaki, poznać Jego wolę. Potrzebna jest refleksja, wewnętrzne wyciszenie. Jako nastolatce dane mi było ,zasmakować” długich chwil ciszy, kiedy mogłam pogłębić swoje poszukiwanie, aby posłuchać, co mówi do mnie Bóg w głębi serca. Należałam do Oazy, gdzie przeszłam pełną formację od Dzieci Bożych do III stopnia: wspólne Msze św., adoracje, wyjazdy na rekolekcje. Cotygodniowe spotkania pogłębiły moją wiarę i miłość do Jezusa (siostra zakonna, lat 40).

Teraz wspominając moje życie, widzę, że Pan już od dziecka przygotowywał mnie do tej roli, abym w przyszłości została zakonnicą, jednak wtedy nie zdawałam sobie z tego sprawy. Będąc w szkole podstawowej, podświadomie szukałam towarzystwa sióstr zakonnych, często po katechezie zostawałam, aby porozmawiać z siostrą; w parafii pomagałam siostrom w różnych pracach (siostra Maria Filomena).

Gdy myślę „moje powołanie”, podświadomie koncentruję się na jednej chwili w moim życiu. I choć wiem, że to wezwanie mnie po imieniu do życia we wspólnocie zakonnej Sióstr Misjonarek Świętej Rodziny było od zawsze w Bożym planie i że wszystkie uprzednie wydarzenia prowadziły do odkrycia tej mojej własnej drogi, to wciąż kluczowe znaczenie ma dla mnie ten moment, gdy po raz pierwszy w życiu bardzo intensywnie dane mi było doświadczyć Bożego zaproszenia, by żyć w czystości, ubóstwie i posłuszeństwie [...]. Ten tydzień pod koniec sierpnia trwa we mnie wciąż żywy. To, co się wówczas dokonało, owocuje i stanowi niezbędny pryzmat dla moich codziennych wyborów. Czuję, że nigdy nie mogę być wystarczająco wdzięczna za ten błysk, dzięki któremu wszystko stało się jasne i wyraźne, za tę łaskę pewności, która chyba nikomu zdrowo myślącemu nie mogłaby zasugerować decyzji o odrzuceniu szczęścia, za to doświadczenie, że dokładnie wszystkie „puzzle” - te z przeszłości zarówno pełnej światła, jak i mrocznej - utworzyły harmonijną całość (siostra Lena).

Niektórzy „religijni wirtuozi”, ludzie głęboko wierzący, charakteryzują się mentalnością mirakularną, są przekonani, że w świecie obok naturalnych procesów zachodzą też zjawiska nadnaturalne, cudowne (Zi m n i ca-K u zi o ła 2013: 167). Ciekawe, że tylko w jednym świadectwie pojawiła się relacja o tego typu fenomenach:

Powiedziałam: „Panie, jeżeli chcesz żebym kroczyła tą drogą, to powiedz mi to teraz...”. Nigdy nie zapomnę, jak po wypowiedzeniu w sercu tych słów, przez kilka sekund zaczął wiać 
mocny wiatr... którego w tym dniu w ogóle nie było... wtedy oprócz radości pojawił się również spokój... (siostra M. Paula) $)^{5}$.

W obliczu tak trudnej decyzji, jaką jest wybór stanu zakonnego, zupełnie naturalne jest pojawienie się uczuć i myśli ambiwalentnych. Siostry relacjonują okresy niepewności, wahania, podczas których szukały jakiegoś potwierdzenia, „znaku”, że obrały dobrą drogę. Z jednej strony odczuwały głębokie zainteresowanie życiem duchowym, z drugiej - przeżywały rozterki, miały wątpliwości, czy potrafią zrezygnować z tego wszystkiego, co oferuje im świat. Zdawały sobie sprawę, że emigracja za klauzurę jest równoznaczna z rozłąką z „ojczyzną prywatną", z dotychczasowym środowiskiem. Co więcej, w przypadku zgromadzeń kontemplacyjnych jest to emigracja bez możliwości wyjazdów i powrotów. O tej wewnętrznej walce siostry mówią w następujący sposób:

W klasie maturalnej pojawiły się pierwsze obawy, lęki, niepewności, zakochanie. Chciałam pokazać Bogu, że ja się nie nadaję, uciekałam od Niego, chciałam oddalić się od Kościoła, lecz nie mogłam. Jak zrezygnować nagle z pokarmu, który przyjmowałam przez ostatnie kilka lat codziennie? Chociaż chciałam, nie mogłam [...]. Wszyscy wokół mówili: „Będziesz zakonnicą”, a ja z wielkim zdecydowaniem i pewnością odpowiadałam: „Nigdy!”. Miałam wiele pragnień, marzeń, które chciałam zrealizować, a żadne z nich nie prowadziło mnie do furty klasztornej (siostra Ewa).

Pytanie jednej z sióstr: „Czy ty nie myślisz o życiu zakonnym?”. I znowu mój uśmiech: „Ja?! Skądże znowu! To nie dla mnie! Mam inne plany”. Tak. Ale to były MOJE plany, a nie Boże. To pytanie, nieoczekiwanie dla mnie, wciąż powracało. Nieustannie brzmiało w moich uszach. Uciekałam przed nim. Odgradzałam się od niego moimi planami. Wszystko na nic. Wracało jak bumerang. Im silniej je odpychałam, tym szybciej drążyło mnie na nowo. Przez pół roku trwała ta walka. Bitwa o moje ,ja tak chcę" (siostra Michała).

Za dwa tygodnie matura. Patrzyłam na rozłożone książki. Z serca do Boga wyrywał się głos, by pomógł mi zrozumieć, czego chce od mojego życia, co mam wybrać: studia, wyjazd za granicę, czy to, przed czym drżę najbardziej - zostać siostrą zakonną [...]. Napisałam do Sióstr Misjonarek Świętej Rodziny. Szczerze wyznałam, co przeżywam, jakie lęki i niepokoje mnie trapią, jaką mam rodzinę, jaka sama jestem. Po wysłaniu listu trochę pocieszałam się, że jak siostry mnie poznają, to powiedzą, że zakon jest nie dla mnie. A tu nieoczekiwanie szybko otrzymuję odpowiedź: „Przyjedź, porozmawiamy o tym więcej”. Potem wszystko potoczyło się błyskawicznie: długa i szczera rozmowa z siostrą; rekolekcję w domu nowicjatu, gdzie jeszcze wykłócałam się z Panem Jezusem, że na pewno się myli, ja się nie nadaję (siostra Joela).

${ }^{5}$ W kontekście zbiegów okoliczności, które podlegają religijnym atrybucjom, warto przytoczyć historię siostry Neriny z czynnego zgromadzenia sióstr boromeuszek (Sióstr Miłosierdzia św. Karola Boromeusza). Gdy przychodziła na świat, jej życie było zagrożone, przeżyła dzięki siostrze zakonnej, która posługiwała w szpitalu. Siostra - położna - stwierdziła: „to może ta mała kiedyś mnie zastąpi?”. Gdy 20 lat później „ta mała” zaczęła postulat, okazało się, że właśnie siostry z tego zgromadzenia, z tego konkretnego klasztoru, pracowały w szpitalu, w którym ona przyszła na świat. Udało jej się też dowiedzieć, kim była siostra, której zawdzięczała życie. Przyjęła jej imię zakonne i także podjęła się pracy w szpitalu (http://boromeuszki.pl/moje-powolanie-to/swiadectwa-siostr, 20.02.2015). 
Rozterki kończą się wraz z podjęciem ostatecznej decyzji. Punktem zwrotnym, który można także określić przełomem biograficznym, bywa spotkanie ze „znaczącym innym”, rekolekcje, lektura książki religijnej. Pojawia się wówczas silny bodziec, przesądzający o wyborze życiowej drogi:

Pan Jezus postawił na drodze mego życia pewnego Ojca, franciszkanina z Polski. Spotkałam go właśnie na Mszy św. i z jego ręki przyjęłam Komunię św. On powiedział do mnie wtedy te proste słowa po angielsku (nie znałam wtedy języka polskiego): „Nie bój się iść za Jezusem”. Nagle zrozumiałam, że są to słowa nie jakiegoś nieznanego kapłana, ale Pana Jezusa, skierowane osobiście do mnie, choć zdziwiłam się bardzo, skąd on wie o mojej tajemnicy, że pragnę oddać się Bogu (siostra Faustyna).

Pewnego dnia wpadł mi w ręce żywot św. Ojca Franciszka z Asyżu. Był to moment decydujący. Czytając tę książkę zrozumiałam, że moim powołaniem jest żyć Ewangelią na wzór Biedaczyny z Asyżu i św. Klary (siostra Zofia).

Za niedługi czas podczas Mszy św. odczułam w sobie ogromne pragnienie oddania się Jezusowi poprzez życie zakonne. Było to dla mnie coś niesamowitego, przeżyłam szok. Nie mogłam zrozumieć, dlaczego tak nagle i nie wiedziałam, co dalej robić. Jednakże wewnątrz czułam, że to pochodzi od Boga. Czułam, że właśnie odkryłam powołanie, które było tak blisko mnie (siostra Katarzyna).

Następnym etapem po podjęciu decyzji o emigracji ,ze świata” jest wybór konkretnego zgromadzenia, w czym pomaga wiele okoliczności: zostawiona w kościele broszura reklamująca konkretny zakon, rekolekcje powołaniowe, spotkanie z przedstawicielką danego zgromadzenia itd. Czasem wybór poprzedzony jest długim namysłem, podyktowany znajomością specyfiki konkretnego zakonu (w czym obecnie pomaga Internet). Charakterystyczne, że wybór z reguły uznawany jest za implementację boskiego planu:

Zdecydowana byłam wstąpić do zakonu kontemplacyjnego, ale nie wiedziałam, gdzie się udać. O zakonie Sióstr Klarysek nic nie wiedziałam, nawet o tym, czy istnieją w Polsce. I oto nagle dowiedziałam się, że moja starsza koleżanka, z którą się przyjaźniłam, wstępuje do zakonu kontemplacyjnego - i to właśnie do Klarysek! Moje zdumienie i moja radość były trudne do opisania! Czyż nie był to zamysł Boży? (siostra Zofia).

Nie wiedziałam, do jakiego charyzmatu Bóg mnie powołuje. Podtrzymywałam kontakty z różnymi czynnymi zgromadzeniami, jednak nie miałam w sercu pewności [...]. Wtedy na jednym z młodzieżowych spotkań przy klasztorze redemptorystów poznałam s. Marię Slepchenko - redemptorystkę z Bielska-Białej, która przebywała wówczas w swoim rodzinnym mieście. Jakiś czas po tym spotkaniu przeczytałam porywające ogłoszenie, że siostry redemptorystki kontemplacyjne - klauzurowe będą prowadzić rekolekcje powołaniowe dla dziewcząt. Odczułam w sercu, że mam być na tych rekolekcjach (siostra Maria).

I oto teraz, na dwa tygodnie przed maturą, Mamusia jakby czytając mi w sercu, przynosi mi „to, czego szukałam”. Jak zahipnotyzowana czytałam kolejno adresy. Moją uwagę przykuł szczególnie jeden z nich: „Siostry Misjonarki Świętej Rodziny. Charyzmat - »Aby wszyscy stanowili jedno«. Misje - Wschód, Afryka, Ameryka". Bez wahania zakreśliłam ten adres (siostra Joela). 
Dla rodziny, która dowiaduje się o emigracyjnych planach dziewczyny, jest to nierzadko bardzo trudne doświadczenie. Nawet jeśli bliscy podzielają jej religijny entuzjazm i teoretycznie nie mają nic przeciwko temu wyborowi, odczuwają negatywne emocje związane z rozstaniem, z zerwaniem fizycznej relacji. Jest jeszcze trudniej, jeśli in extenso nie akceptują jej decyzji i próbują odwieść ją od nieracjonalnego, by nie powiedzieć aberracyjnego - w ich mniemaniu - zamiaru. Zwierzenia sióstr dowodzą, że sprzeciw rodziny sprawia dodatkowy dyskomfort, a niezmiernie rzadko prowadzi do rezygnacji z wyjazdu do klauzurowego świata:

Termin wyjazdu powoli się zbliżał. Już miałam spakowane rzeczy, a przecież wciąż nie mogłam odważyć się na krok decydujący, aby powiedzieć ojcu o wyjeździe. Wreszcie wieczorem, w przeddzień wyjazdu, wykrztusiłam z niemałym trudem to ciężkie wyznanie. Ojciec się rozpłakał. Moja decyzja spadła na niego jak grom z jasnego nieba. Nie sprzeciwiał się. Wiadomość o moim kroku w kierunku podjęcia życia kontemplacyjnego przygniotła go jednak tak bardzo, że jeszcze nawet gdy przyjechał na moje obłóczyny, znów płakał i znać na nim było jeszcze ból i smutek rozłąki (siostra Zofia).

Najciężej było patrzeć na łzy Mamy proszącej, bym zaczekała jeszcze kilka lat. Cieszyła się moją decyzją, lecz uważała, że jestem za młoda na wstąpienie do zakonu. Tatuś odwrócił się ode mnie, nie chciał zgodzić się na wybraną przeze mnie drogę życia (siostra Joela).

Przygotowania nie były łatwe, wszystko robiłam w ukryciu, w czym bardzo skrzętnie przeszkadzali mi moja siostra Beata (dziś także siostra zakonna) i brat Janusz. Cóż też oni na mnie nie wymyślali, ale z czasem przyzwyczaili się do tej myśli, że będą mieć w rodzinie ,pingwina" (siostra Nerina).

Emigracja ze świata nieklauzurowego wiąże się z refleksją nad tym, co się zostawia, co się traci. Siostry nie piszą o rzeczach materialnych, niemal zawsze expressis verbis wskazują na trudność zerwania bezpośrednich relacji z najbliższymi. Wybierając zakon, muszą wyrzec się bliskości z drugim człowiekiem, życia rodzinnego, macierzyństwa:

Najbardziej mnie jednak odstraszało to, że z rodziną będę się widzieć tylko przez kraty i nigdy nie będę mogła odwiedzić najbliższych [...]. Jedynym problemem było rozstanie z rodzicami (dobrze, że blisko - $25 \mathrm{~km}$ od Wrocławia), któremu towarzyszyły niezręcznie skrywane łzy po obu stronach. Ale mocno ufałam w opanowanie tej nostalgii i się nie zawiodłam (siostra M. Klara).

Ponieważ byłam przedszkolanką, opiekowałam się dziećmi w rodzinach w różnych krajach. Poznałam jak piękne może być życie małżonków, którzy się szczerze kochają i cieszą się swoimi dziećmi. Jednak już wtedy przeczuwałam, że moja droga będzie inna, ja tęskniłam za Kimś, kto jest większy... (siostra Faustyna).

Nazajutrz rano w towarzystwie starszej siostry udałam się w podróż, żegnając cały ten piękny świat, w którym wzrastałam od dzieciństwa. Było to moje największe bogactwo, którego świadomie wyrzekłam się dla Boga (siostra Zofia). 
Oczywiste i zrozumiałe, że czasem emigrantkę ze świata ogarnia żal za zwykłymi, codziennymi przyjemnościami:

Pamiętam, że kiedyś przed wstąpieniem do klasztoru otworzyłam szafę z ubraniami. Było ich tam sporo. Zrobiło mi się żal, gdy pomyślałam sobie, że za niedługo mój strój będzie tylko jedno- lub dwukolorowy i że już nie będę się mogła stroić (siostra Dorota).

Większość sióstr zapewnia, że nowe miejsce pobytu spełniło ich oczekiwania, było zgodne z wyobrażeniami. W świadectwach kilku z nich pojawia się relacja o pierwszym wrażeniu w nowej rzeczywistości. Rejestrują pozytywne emocje, jakie im wówczas towarzyszyły (charakterystyczne są słowa jednej z mniszek: „wstępowałam do portu”, czyli do miejsca przeznaczenia):

Spotkałam się z serdecznym przyjęciem i prostotą życia sióstr, które wypełniają słowa Jezusa: „Po tym wszyscy poznają, żeście uczniami moimi, jeśli będziecie się wzajemnie miłowali” $(\mathrm{J} 13,35)$ (siostra Maria).

Wszystko przemawiało do mnie w tym zakonie: duch, reguła, forma życia i strój zakonny. Siostry pogodne, proste, wesołe i pełne miłości Bożej oraz życzliwości, z radością witały nowicjuszkę [...]. Przybyłam do klasztoru w godzinach porannych. Po krótkiej rozmowie przy furcie otworzyły się przede mną ciężkie wrota klasztorne, a ja wstępowałam do portu po raz pierwszy w życiu naprawdę szczęśliwa i bezpieczna. Matka ksieni i siostra mistrzyni zaprowadziły mnie do kaplicy przed ołtarz Matki Bożej, następnie do celi zakonnej, gdzie miałam zamieszkać. Cela zrobiła na mnie niezwykłe wrażenie. Bielutki, sklepiony pokoik, pełen był ciszy i słońca: „Tu miejsce odpocznienia mego, tu mieszkać będę, bom je obrała” (siostra Zofia).

Niemniej niektóre siostry szczerze przyznają, że adaptacja do nowych warunków nie przebiegała bezproblemowo: „Jak każde początki są trudne, tak i tu nie było mi łatwo" - wyznaje siostra Ewa. W początkowym okresie nowe schematy myślenia i działania interferują z dotychczasowymi wzorami zachowań. Poczucie niepewności towarzyszy zwykle fazie liminalnej, czyli okresowi przejściowemu', w którym następuje przyjmowanie nowej roli i nabywanie tożsamości zakonnej. Aklimatyzacja powinna kończyć się pełnym zaangażowaniem w realizację reguł przypisanych roli i pełną identyfikacją z charyzmatem zakonu, ze wspólnotą. Jednak można $\mathrm{z}$ dużym prawdopodobieństwem założyć, że przedemigracyjna tożsamość nie bez trudu ustępuje miejsca nowej, klauzurowej. Siostry nie opowiadają jednak o kulisach, o realiach zakonnych. Świadectwo, które ma zachęcić kandydatki na mniszki, wyklucza dyskurs na temat prozy życia za klauzurą.

${ }^{6}$ O liminalności jako kategorii przydatnej w opisie doświadczenia migracyjnego pisze Tomasz Ferenc. Autor stwierdza: „Początkowy okres migracji jest formą przejścia z jednej znanej rzeczywistości w drugą, często obcą i nieznaną [...]. Okres ten cechuje się zatem zawieszeniem i niepewnością; jednostka, rozpoznając obcą sobie rzeczywistość, zdobywa nowe doświadczenia, podejmuje próby zorganizowania od nowa swojego życia. Od rezultatu tych prób uzależniona jest decyzja o pozostaniu lub powrocie do kraju" (F e r e n c 2012: 193). 
Nie można mówić o tęsknocie i zniechęceniu, o ograniczeniu wolności osobistej, o konieczności koegzystencji z ludźmi, których towarzystwa się nie wybierało. Zgodnie z ideą „tekstu perswazyjnego" (jest to perswazja pobudzająca, przekonująca i nakłaniająca) kolejnym obligatoryjnym punktem relacji jest zapewnienie o własnym szczęściu i radości. Siostry piszą zatem o poczuciu zadowolenia z dokonanego wyboru, zapewniają, że ich życie jest dobre i wartościowe, a zwyczajne troski i problemy bytowe nie przesłaniają im radości życia, które ma - w ich przekonaniu - głęboki sens. Mniszki są pewne tego, że ich wyrzeczenie, cierpienia i modlitwy mają realny wpływ na losy świata. Mówią o dobrostanie psychicznym, o satysfakcji, której źródłem jest poczucie misyjności, bezinteresowne działanie na rzecz innych, zjednoczenie wokół „wspólnej sprawy”. Dyskurs zewnętrzny (dokumenty dotyczące życia konsekrowanego, homilie przedstawicieli Kościoła itp.) utwierdza je w przekonaniu o tym, że zostały wybrane i obdarzone specjalnym posłannictwem. Gratyfikacją dla nich jest też hiperaktywacja systemu przywiązania, duża intensywność kontaktów z sacrum, styl życia, zgodny z naturalnymi predyspozycjami:

W klasztorze jestem bardzo szczęśliwa, nieustannie dziękuję Bogu za dar mojego powołania; za to, że On przez tyle lat czekał na mnie, był blisko, kiedy szukałam Go na całym świecie, a znalazłam Go w moim sercu (siostra Faustyna).

Po tylu latach zakonnej formacji jestem bardzo szczęśliwa i czuję się na swoim miejscu. Osiągnęłam wszystko, czego pragnęłam. W tym miejscu niech mi będzie wolno wyznać - dla lepszego zrozumienia zakonnego powołania - jedną, zasadniczą prawdę. Pragnę wyjaśnić, na czym polega szczęście w klasztorze. To nie jest życie bez cierpień, wolne od wszelkich trosk. To jest życie, w którym radość czerpie się z łaski zamieszkiwania z Bogiem pod jednym dachem, z możliwości cierpienia dla Niego. Wszelkie moje troski obejmują cały świat, Kościół powszechny, wszystkich ludzi wierzących i niewierzących. Za klasztorną kratą Bóg dzieli się bowiem wszystkimi swymi pragnieniami ze swoimi oblubienicami, które sam wybrał spośród świata tego, jedynymi spośród wielu (siostra Zofia).

Zdumiało mnie to, że właśnie w klauzurze poczułam ogromną wolność i radość bycia z Jezusem oraz we wspólnocie, czego wcześniej nie przeżywałam w świecie. Otwarcie na Boga uczyniło mnie bardziej sobą, twórczą (siostra Maria).

Zakony, aby petryfikować własne struktury, potrzebują nowych kadr, tymczasem od dłuższego czasu statystycy kościelni odnotowują spadek liczby powołań? Podstawową funkcją świadectw jest zatem dodanie odwagi tym dziewczętom/

${ }^{7}$ J. Baniak stwierdza: „W ostatniej dekadzie XX wieku i pierwszej dekadzie XXI wieku nastąpił radykalny spadek liczebności powołań kapłańskich i zakonnych, który nadal się utrzymuje” (B a n i a k 2012: 24). Na podstawie Leksykonu zakonów w Polsce B. Łozińskiego Katarzyna Świerczyńska pisze: „Jak wynika ze statystyk kościelnych, liczba nowicjuszek spadła w ciągu ostatnich siedmiu lat z 1188 do zaledwie 613 [...]. Ale nie lepiej jest w zgromadzeniach męskich: liczba nowicjuszy spadła w nich z 700 przed 7 laty do nieco ponad 300 obecnie" (Ś w i e r c z y ń s k a 2009). 
kobietom, które się jeszcze wahają, czy emigrować do zamkniętego świata za klauzurą. Zachęta do wyboru właśnie takiej drogi życia kończy się prozelityczną apostrofą do potencjalnej zakonnicy:

Jeśli nie boisz się radykalnie wejść w siebie, zostawiając w domu przyjaciół, komputer, MP3 i 4, telefon, tylko po to, by móc w prawdzie stanąć przed sobą i Bogiem w CISZY KARMELU... Jeśli chcesz porozmawiać, napisz.

Wszystkim, których Bóg wzywa chcę powiedzieć: „Nie lękaj się!”. Jezus jest Pokojem, w Nim nie ma lęku. A nawet jeśli jest trudno, to dla Jezusa warto.

Ty, moja Droga, masz na pewno jeszcze wiele innych problemów, ale chcę Cię zapewnić, że Chrystus znajdzie radę na każdy z nich, jeśli tylko mu zaufasz. Z Nim pokonasz wszelkie trudności. On wymaga od Ciebie bardzo niewiele, a za wszystko stokrotnie wynagradza. Chce przede wszystkim, byś zechciała być wyłącznie Jego, do Jego dyspozycji, pójść tam, gdzie Cię pośle, do prac i zajęć, które być może nie zawsze będą Ci sprawiały przyjemność. Chce, abyś Go we wszystkim naśladowała, abyś była dla wszystkich dobra i miłosierna, abyś wiernie wypełniała Jego wolę. Chrystus już wybrał. Teraz czeka na Twoją decyzję, na Twoje „tak” (siostra Dorota).

Siostry zakonne utrzymują się same, żyją bardzo skromnie. Przyznają, że czasem brakuje im środków na podstawowe potrzeby bytowe. Otrzymują e-maile, listowne prośby o modlitwy w wielu intencjach (np. o zdrowie, nawrócenie kogoś bliskiego), do próśb często dołączone są ofiary pieniężne ${ }^{8}$. W związku z problemami materialnymi niektóre zakonnice kończą swoje świadectwa apelem o wsparcie finansowe, dofinansowanie budowy klasztoru itd.

Można pytać, czy tryb życia sióstr klauzurowych jest zgodny z regułami zdrowia psychicznego. Życie we wspólnocie, rutyna dnia codziennego, posłuszeństwo, ubóstwo, wyrzeczenie się naturalnych pragnień, podporządkowanie regule i zwierzchnikom zdają się nie przeszkadzać siostrom, które wszystko, co je spotyka, odnoszą do tego, co transcendentne. Oficjalny dyskurs wyklucza zwierzenia o problemach, trudnościach, Co prawda, nieliczne siostry otwarcie przyznają się do kryzysu, ale tylko po to, aby zapewnić, że to jest stan naturalny i łatwo można przezwyciężyć zniechęcenie. Takie relacje jak poniższe pojawiają się tylko incydentalnie:

8 „Socjolog religii postrzega modlitwę zakonnic i zakonników jako rodzaj »pracy«, której efekty i środki służą ich codziennemu utrzymaniu i funkcjonowaniu w społeczeństwie. Katolicy świeccy bardzo często proszą te zakony o modlitwę w sprawach osobistych, rodzinnych, społecznych czy religijnych i moralnych, zlecając im ją w formie posługi religijnej, a za jej wykonanie przekazują zakonnicom i zakonnikom środki finansowe lub inne dobra materialne, potrzebne im do zwykłego funkcjonowania na co dzień, jak i własnych wspólnot jako całości. Z badań wiadomo, że coraz częściej katolicy świeccy zatracają umiejętność i chęć osobistej modlitwy, natomiast niektórzy, doceniając jej rolę w swoim sproblematyzowanym życiu, proszą o nią właśnie zakony kontemplacyjne" (B a n i a 2012 : 184). 
Gdy słyszałam, o jakiej porze Siostry są już na modlitwie, byłam niepocieszona, bo wydawało mi się to takie trudne. Obecnie moja wspólnota gromadzi się w kaplicy o godz. 5.10 (siostra Dorota).

W pierwszych latach życia zakonnego, gdy byłam nowicjuszką, przeżyłam kryzys w powołaniu. Moja tęsknota za domem rodzinnym była tak wielka, że postanowiłam wrócić do Rodziców. Ukrywając przed siostrami prawdziwy powód wystąpienia, po wielokrotnych rozmowach z s. Mistrzynią i Matką Przełożoną, podjęłam decyzję powrotu. Nikogo na siłę nie można zmusić do pozostania w klasztorze (siostra zakonna, lat 42).

Siostry z zakonów kontemplacyjnych, izolowane od świata zewnętrznego, mają szansę utrzymania swej subtożsamości religijnej, jednak okazuje się, że laicyzacja wkrada się także za klauzurę. Powodem jest choćby konieczność korzystania z nowoczesnych form komunikacji ze światem. Oto ciekawy komentarz jednej z zakonnic:

Z klauzury bowiem można „wyjśś” także „drzwiami Internetu” [...] wielką pomocą w pracy są komputerowe maszyny do szycia i haftu. Obsługa komputera wymaga jednak przygotowania i może okazać się konieczny specjalny kurs dla grupy mniszek, co wiąże się z wyjściem z klauzury. Na takie i podobne inicjatywy dla dobra i ubogacenia naszych Wspólnot powinnyśmy być otwarte. Równocześnie usterki w nowoczesnym sprzęcie elektronicznym wymagają zazwyczaj interwencji fachowca, dlatego posiadanie takiego sprzętu zakłada z kolei konieczność częstszego wpuszczania ludzi za klauzurę. I z tym też chyba musimy się pogodzić (Gołębiowska 2009).

Kryzys powołań, który dotyka wspólnoty życia konsekrowanego, wynika z wielu czynników, m.in. z kryzysu wiary i zmniejszenia się społecznego prestiżu osób duchownych. Psychologowie zwracają uwagę na postawy współczesnych młodych ludzi, którzy odsuwają w czasie ważne życiowe wybory, zatem także te dotyczące „emigracji klauzurowej”. Okazuje się, że istotnym problemem jest niedojrzała osobowość kandydatek na siostry zakonne9. Według kościelnych ekspertów powołaniom nie sprzyjają masowe media, które prezentują modele życia

${ }^{9}$ Niesłychanie długa jest lista zastrzeżeń, jakie wysunęła jedna z sióstr pod adresem młodych mniszek: „Bardzo ograniczona wiedza religijna i to nawet podstawowa, katechizmowa mentalność wirtualna, która jest naturalnym skutkiem dzisiejszej mentalności zlaicyzowanej i relatywistycznej. Wyobcowanie z realiów codziennego życia, samowola, niezdolność do podejmowania trwałych decyzji życiowych; słaba wola, nieumiejętność słuchania, chwiejność, niepewność, silnie emocjonalne przywiązanie do rodziny; mentalność konformistyczna, nastawienie na szybki efekt; indywidualizm, egocentryzm, brak tolerancji, niecierpliwość, impulsywność, niezależność, nastawienie na to, co łatwe, przyjemne, wygodne; brak zrozumienia ducha ofiary, pokuty, wyrzeczenia; nadmierna uczuciowość, patologiczna wprost nadwrażliwość, trudności w przyjmowaniu uwag i upomnień nawet od przełożonych; trudności w koncentracji; brak zrozumienia wartości milczenia; trudności wynikające z przyzwyczajenia do prawie nieustannego słuchania muzyki; skłonność do hipochondrii, lekomanii i anoreksji, słabsze zdrowie fizyczne, słabsza odporność psychiczna; nierzadko próżność, zbytnia troska o wygląd" (G o ł ę b i o w s k a 2009). 
dalekie od idealizmu i bezinteresowności. Jedna z sióstr uczestnicząca w dyskusji na temat przemian kulturowych determinujących życie wspólnot kontemplacyjnych mówi o „mentalności wirtualnej” młodych ludzi, wyrażającej się poszukiwaniem rozrywek, duchową pustką i chaosem aksjologicznym. Przekłada się to na wzory myślenia i zachowania młodych postulantek i nowicjuszek. Emigrantki klauzurowe przybywają przecież z tego - zdominowanego medialnie - świata. Na podstawie wypowiedzi „specjalistki od powołań” (G oł ę bi ow s k a 2009) można nakreślić idealny (postulowany) wizerunek zakonnicy: mniszka powinna mieć pogłębioną wiedzę religijną, ukształtowaną, stabilną osobowość, zdrowie fizyczne i psychiczne. Wysoko waloryzowana jest umiejętność rezygnacji z pragnień i indywidualnych dążeń na rzecz wspólnoty. Siostra zakonna składa śluby posłuszeństwa, czystości i ubóstwa - łatwiej jej wypełnić te zobowiązania, jeśli potrafi narzucić sobie dyscyplinę i żyć ascetycznie. Jej religijność powinna być allocentryczna, dojrzała, tzn. przedmiot doświadczenia - Bóg - nie może być traktowany instrumentalnie, ale stanowić najwyższą centralną wartość (por. P i w ow a r ski, Tomkiewicz 1991: 180) ${ }^{10}$.

Świadectwo jako forma wypowiedzi często stosowana w dyskursie religijnym może być przedmiotem analizy lingwistycznej ${ }^{11}$. Siostry w swoich pisemnych relacjach wykorzystują liczne środki retoryczne wzmacniające ekspresję i emocjonalność przekazu. Często stosują porównania, metafory, analogie i emfazy, które nadają ich świadectwom patetyczny charakter; hyperochy, czyli najwyższe pochwały (,Niech będzie Bóg uwielbiony za wszelkie cuda, jakie czyni w naszym życiu; za to, że czyni nas bardziej szczęśliwymi niż my pragniemy, niż my sobie to wyobrażamy. Daje o wiele więcej i pełniej niż my potrafimy to sobie wyobrazić" - siostra Katarzyna); pytania retoryczne sugerujące oczywistość przekazywanego sensu. Niektóre siostry swoje teksty kończą apostrofą („Boże, powołałeś mnie... Nie mogę zrozumieć miłości, którą dajesz mi... Dziękuję Tobie, o Panie!" - siostra Joela) bądź doksologią, czyli formułą głoszącą wszechmoc Boga. Czasem układają wiersze (najczęściej nieporadne, „,zęstochowskie rymy", które pokazują jednak intensywność emocji, siłę zaangażowania w relację z Doskonałym Obiektem Przywiązania). Bardziej utalentowane mówią poetycko: „Zajmij moje miejsce. Bądź sercem mojego serca, spojrzeniem moich oczu, uśmiechem moich ust, słowami miłości mojego języka" (siostra zakonna, lat 46). Afektywny charakter i autentyczność ich wypowiedzi podkreślają znaki interpunkcyjne (wykrzykniki, wielokropki, myślniki, pytajniki). Siostry cytują frag-

${ }^{10} \mathrm{~W}$ literaturze przedmiotu (psychologicznej) istnieje wiele prób adekwatnego ujęcia istoty dojrzałej religijności. Najczęściej zwraca się uwagę na jej autonomiczny charakter, autentyczność przekonań religijnych, holizm („,dojrzała religijność przenika wszelką aktywność jednostki, wypełnia jej życie znaczeniem" - pisze, za G. W. Allportem, Paweł S o c h a [1991: 64]). Problem ten poruszają także: Pr ęż y n a (1990), C h le w iń s ki (1990), J a w o r s k i (1989).

${ }^{11}$ Pionierską pozycją dotyczącą tego zagadnienia jest książka Małgorzaty Danuty N o w a k (2005). 
menty Pisma Świętego i krótkie maksymy stanowiące dla nich życiowe motta. Już pobieżna analiza lingwistyczna świadectw dowodzi osobistego stosunku ich autorek do rzeczywistości sakralnej. Słowa wyrażają ich własne doświadczenia, w pewnym sensie niepowtarzalne, ale dające się sprowadzić do tego, co intersubiektywne i uniwersalne.

\section{Podsumowanie}

Na podstawie lektury relacji (świadectw) sióstr zakonnych, należących do różnych zgromadzeń, mogę powiedzieć, że o emigracji do świata klauzurowego decydują trzy czynniki, wszystkie zapewne jednakowo ważne: cechy osobowościowe (indywidualne predyspozycje), religijna socjalizacja i aktywność zmierzająca do rozwoju życia duchowego. Można je wizualnie ukazać na poniższym schemacie:

Czynniki decydujące o emigracji do świata za klauzurą

$\begin{array}{ccc}\Downarrow & \Downarrow & \Downarrow \\ \text { osobowość } & \text { socjalizacja religijna } & \text { aktywność własna }\end{array}$

Aspirantki do życia zakonnego odczuwają autentyczne zainteresowanie sferą religijną, cenią samotność, która sprzyja introspekcji i duchowemu rozwojowi:

Zawsze lubiłam ludzi, którzy lubią ciszę, spokój, śpiew, Biblię [...]. Bo czyż to normalne, że szesnastoletnia dziewczyna nie lubi tego, za czym szaleją jej rówieśnicy? Kochałam ciszę, oni głośną muzykę, oni pełny dom roztańczonych młodych, a ja samotność przy zapalonej czerwonej lampce, która dawała mi znak, że On jest i czeka na mnie. Był to świat niezrozumiały dla mnie, ale tajemniczy i pociągający (siostra Agnieszka).

Powołanie rozwija się na gruncie religijnej socjalizacji (pierwotnej i wtórnej), relewantne jest w tym procesie świadectwo ,znaczącego innego"12:

W tym samym czasie na mojej drodze pojawił się kleryk (obecnie kapłan misjonarz, sercanin). Było to podczas Sercańskich Dni Młodych w Pliszczynie. Już przy pierwszym spotkaniu opowiedział mi historię swojego powołania, swojej relacji z Jezusem. Nie wiedziałam, po co on mi to mówi, ale z wielkim zainteresowaniem go słuchałam. Do tego czasu chyba nigdy nie spotkałam człowieka, który z taką miłością mówiłby o Bogu. Myślałam sobie: „Ależ on kocha Boga”. Nasza rozmowa trwała bardzo długo, kilka godzin. Wierzę, że Bóg dał mi tego człowieka, bym mogła przez niego usłyszeć Jego samego (siostra Agnieszka).

${ }^{12}$ Bez ,zaplecza” środowiskowego trudno wyobrazić sobie klauzurową emigrację. Prawdy wiary przekazuje religijna wspólnota, toteż religijne doświadczenie jest przez nią stymulowane i kształtowane. O społecznym wymiarze wiary pisze m.in. G i u s s a n i (2000: 206). 
Dwa powyższe czynniki byłyby jednak niewystarczające bez podmiotowej aktywności jednostki. Warunkiem sine qua non konkretyzacji życiowych planów jest zatem podjęcie określonych działań. Egzemplifikacją może być wypowiedź siostry Ewy:

Miałam jeszcze jedno, ale ciche zainteresowanie. Było to czytanie Pisma Świętego. Nie wiem, dlaczego tak bardzo lubiłam je czytać, zwłaszcza Ewangelie, a w nich opowiadania o tym, jak Jezus uzdrawiał, czynił cuda. Prawie nic nie rozumiałam. Po szkole podstawowej rozpoczęłam naukę w szkole średniej. Nowa miejscowość, nowa szkoła, grono znajomych powiększyło się, nowa parafia. Już w pierwszym dniu szkoły średniej odnalazłam drogę do kościoła, którą przez cały okres nauki wydeptywałam, biegnąc na poranną Mszę św. jeszcze przed zajęciami. Nie było ani jednego dnia, którego bym nie rozpoczęła od spotkania z Jezusem w Eucharystii [...]. Rozpoczęły się wyjazdy na rekolekcje, czuwania. Wstąpiłam do wspólnoty Apostolstwa Modlitwy. Kościół Jezuitów w Krakowie nie był mi obcy, a klasztor Sióstr Józefitek w Tarnowie stał się moim drugim domem, siostry moimi... siostrami.

Autoprezentacje zakonnic, ich relacje o duchowej i fizycznej emigracji do świata klauzurowego kończą się zazwyczaj zapewnieniem, że podjęły właściwą decyzję. Można mówić o wyraźnej sepizacji ich dyskursu, polegającej na marginalizacji realnych problemów. Nie sposób oprzeć się wrażeniu, że idealizują życie za kratami, przemilczają to, co trudne. Być może satysfakcjonującym wyjaśnieniem ich trwania „poza światem” jest doświadczenie religijne. Nie tyle jest to wierność instytucji (wspólnocie zakonnej), ale podjętemu zobowiązaniu wobec numinosum. Życie na klauzurowej emigracji pewnie nie byłoby możliwe bez wertykalnego odniesienia.

$\mathrm{Z}$ dużym prawdopodobieństwem można założyć, że nie wszystkie „klauzurowe emigrantki" z równym entuzjazmem przyjmują życie, które wybrały. Warto byłoby skonfrontować oficjalny dyskurs, czyli internetowe świadectwa - z założenia apologetyczne, gloryfikujące pobyt $\mathrm{w}$ zakonie - $\mathrm{z}$ wypowiedziami sióstr, które, być może uznając zakon za instytucję totalną, wracają z zakonnej emigracji do „starej rzeczywistości”. Jak podkreśla socjolog religii, Józef Baniak, w ostatnim dziesięcioleciu zdarza się to coraz częściej (B a n i a k 2012: 211).

\section{Bibliografia}

B a n iak J. (1997), Dynamika powołań kapłańskich i zakonnych w Kościele rzymskokatolickim w Polsce w latach 1900-1994, Zakład Wydawniczy Nomos, Kraków.

B a n i a k J. (2012), Powołanie do kaptaństwa i do życia zakonnego w Polsce w latach 1900-2010. Studium socjologiczne, Wydawnictwo Naukowe Wydziału Nauk Społecznych Uniwersytetu im. Adama Mickiewicza, Poznań.

B e r g e r P. L., L u c k m a n n Th. (2010), Społeczne tworzenie rzeczywistości. Traktat z socjologii wiedzy, PWN, Warszawa.

C h 1 e w iń s k i Z. (1990), Dojrzałość: osobowość, sumienie, religijność, „W drodze”, Poznań. 
Coll in s R. (2011), Łańcuchy rytuatów interakcyjnych, Zakład Wydawniczy Nomos, Kraków.

Dębowska K. (1998), Życie konsekrowane - jego istota $i$ aktualna sytuacja $w$ Polsce, [w:] B. Ło z i ń s k i (red.), Leksykon zakonów w Polsce. Informator o życiu konsekrowanym, Wydawnictwo KAI, Warszawa.

F e r e n c T. (2012), Artysta jako obcy. Socjologiczne studium artystów polskich na emigracji, Wydawnictwo Uniwersytetu Łódzkiego, Wydawnictwo Biblioteki PWSFTviT, Łódź.

G i u s s a n i L. (2000), Zmyst religijny, Wydawnictwo Pallottinum, Poznań.

G 1 o c k Ch., S t a r k R. (1965), Religion and Society in Tension, Rand McNally, Chicago.

J a w or sk i R. (1989), Psychologiczne korelaty religijności personalnej, Redakcja Wydawnictw KUL, Lublin.

Jeli ńska M. (2009), Religijność człowieka w ujęciu teorii przywiązania, [w:] J. K rok os, M. R y ś (red.), Czy rozum jest w konflikcie z wiara? W X rocznicę ogłoszenia encykliki „Fides et ratio", Instytut Papieża Jana Pawła II, Warszawa.

J o n a c z y k Z. (1974), Socjologiczne problemy powołań kapłańskich i zakonnych $w$ diecezji płockiej, „Studia Płockie” 1974, nr 2, s. 275-291.

L is zk ow sk a D. (2010), Życie zakonne w świecie współczesnym, niepublikowana praca licencjacka (promotor prof. Krzysztof Olechnicki), Poznań.

Ło zińs ki B. (2009), Leksykon zakonów w Polsce, Wydawnictwo KAI, Warszawa 2009, Warszawa.

M a r z a k A. (2008), Indywidualizm a wspólnotowość. Studium socjologiczne życia zakonnego, niepublikowana praca magisterska (promotor prof. Anna Matuchniak-Krasuska), Łódź.

Modnicka N. (2007), Doświadczenia religijne w narracjach członków Kościoła Ewangelicznych Chrześcijan w Polsce - refleksje etnologa, [w:] T. D o k tó r (red.), Doświadczenie religijne, Verbinum, Warszawa.

N ow a k M. D. (2005), Świadectwo religijne. Gatunek - język - styl, Wydawnictwo Towarzystwa Naukowego KUL, Lublin.

O t to R. (1993), Świętość. Elementy racjonalne i irracjonalne w pojęciu bóstwa, Wydawnictwo „Thesaurus Press”, Wrocław.

Piwowarski W., Tomki ewicz A. (1991), Doświadczenie religijne, [w:] I. B or owik (red.), Religia a życie codzienne, t. 2, Zakład Wydawniczy Nomos, Kraków.

Pr ęż y n a W. (1990), Symptomy dojrzałej religijności, [w:] W. Tu re k, J. Ma ri ań s k i (red.), Kościół w stużbie człowieka, Warmińskie Wydawnictwo Diecezjalne, Olsztyn.

S o c h a P. (1991), Rozwój psychiczny w kategoriach przemian orientacji religijnych, [w:] I. B o ro w i k (red.), Religia a życie codzienne, t. 2, Zakład Wydawniczy Nomos, Kraków.

Tu rn e r J. H., S te t s J. E. (2009), Socjologia emocji, PWN, Warszawa.

Z d y b i c k a Z. J. (1984), Człowiek i religia, Redakcja Wydawnictw KUL, Lublin.

$\mathrm{Z}$ i m n i c a-K u z i o ł a E. (2013), Polski homo religiosus. Doświadczenie religijne w relacjach potocznych, Wydawnictwo Uniwersytetu Łódzkiego, Łódź.

\section{Relacje sióstr}

Klara, Paula, Ewa, Dorota, Nerina: http://boromeuszki.pl/moje-powolanie-to/swiadectwa-siostr, 20.02.2015.

Maria Filomena: http://siostra-marie-genevieve.blog.onet.p1/2012/10/20/swiadectwo-powolania-siostra-m-filomena-od-maryi-krolowej-pokoju, 20.02.2015.

Faustyna: http://www.klaryski.sandomierz.franciszkanie.pl/powolania/132-swiadectwo-siostry-faustyny, 20.02.2015.

Maria: http://redemptorystki.pl/?q=node/197_20.02.2015.

Ewa: http://www.zakony.pl/index.php?z=z\&c=3\&i=192, 20.02.2015. 
Zofia: http://www.klaryski.sandomierz.franciszkanie.pl/powolania/137-swiadectwo-s-zofii, 20.02.2015.

Michała, Joela, Lena, s. juniorystka, Katarzyna: http://www.misjonarki-swietej-rodziny.org/powolanie_swiadectwa.html, 20.02.2015.

Siostry zakonne (lat 30, 40, 42, 46, 56): http://www.bernardynki.czestochowa.opoka.org.pl/index3-5.html, 20.02.2015.

\title{
Źródla internetowe
}

Gołębi owska A. (2009), Wspólnoty kontemplacyjne i klauzurowe wobec przemian kulturowych, http://www.zyciezakonne.pl/golebiowska-a-wspolnoty-kontemplacyjne-i-klauzurowe-wobec-przemian-kulturowych-29344, 20.02.2015.

KAI 2014, Obudzić świat - list do mniszek klauzurowych, http/www.deon.pl/religia/kosciol-i-swiat/z-zycia-kosciola/art,20615,obudzic-swiat-list-do-mniszek-klauzurowych.html, 20.02.2015.

Klasztor $i$ wspólnota dziś, http://www.imbramowice.norbertanki.org/pl/klasztor-i-wspolnota-dzis, 20.02.2015.

Siostra Maria, kapucynka z Przasnysza, Klauzura - życie zmarnowane?, http://www.katolik. $\mathrm{pl} / 1255,416$. druk? $\mathrm{s}=2,20.02 .2015$.

Tor e 11 ó J. B. (2014), Psychologia powołania, http://www.ostatniaszuflada.pl/wolnosc/psychologia-powolania.html, 20.02.2015.

Modlitewna cisza - wywiad z karmelitanka bosa, http://www.nawracajciesie.xaa.pl/owiadectwa/ o-modlitwie-wywiad-z-karmelitanka-bosa.html, 20.02.2015.

Ś w i e r c z y ń s k a K. (2009), Młodzi nie chca wstępować do zakonu, http://wiadomosci.dziennik. $\mathrm{pl} /$ wydarzenia/artykuly/138127,mlodzi-nie-chca-wstepowac-do-zakonu.html, 20.02.2015.

\section{Emilia Zimnica-Kuzioła}

\section{EMIGRATION TO THE ENCLOSED WORLD - BASED ON THE NUNS' ACCOUNTS}

\begin{abstract}
The author's aim is to analyze the nuns' accounts on their spiritual and physical emigration to the enclosed world. Out of several dozen of sisters' statements on their vocation, deriving from all sorts Polish religious congregations, the most engaging and extensive ones were chosen. The texts (altogether 20), placed on orders' websites, were submitted to content analysis, aimed at isolating the dominant threads. They have an important cognitive value and present the dynamics of the vocation, which is not only a personal act, but also a social phenomenon; allow to distinguish factors that determine the choice of this unique way of life. Apart from the segmentation of the accounts according to the semantic key, in the basic scope also their linguistic features were taken into account.
\end{abstract}

Keywords: orders in Poland, analysis of nuns' accounts, dynamics of the vocation. 